\title{
PHRASEOLOGICAL UNITS WITH NAMES OF CLOTHES IN ENGLISH, GERMAN AND RUSSIAN
}

\author{
UNIDADES FRASEOLÓGICAS COM NOMES DE ROUPAS EM INGLÊS, ALEMÃO E \\ RUSSO
}

\author{
UNIDADES FRASEOLÓGICAS CON NOMBRES DE ROPA EN INGLÉS, ALEMÁN Y \\ RUSO
}

\author{
Liya Gayazovna YUSUPOVA ${ }^{1}$ \\ Olga Dmitrievna KUZMINA ${ }^{2}$ \\ Marina Igorevna GUSEVA ${ }^{3}$
}

\begin{abstract}
The article deals with the comparative analysis of the English, German and Russian phraseological units with the component "clothes", namely the names of accessories, garments, items of clothing and shoes. The relevance of research is defined by the interest to interaction between different languages and the process of cross-cultural communication in the modern world. A deep study of set expressions helps to learn the unique system of language that is characteristic of its native speakers. The study of phraseological units with the names of clothing opens opportunities for understanding the traditional, material and spiritual culture of a nation. The aim of the study was to compare phraseological units with the component "clothes" of three languages: English, German and Russian and carry out the quantitative analysis of these units. The authors used methods such as descriptive, comparative, interpretative, continuous sampling method and statistical method. The object of the study is different types of phraseological units, including proverbs and sayings, with the names of clothes belonging to five thematic groups: "garments", "clothing items", "clothing materials", "accessories" and "shoes". The study revealed that the biggest thematic groups of phraseological units are those with the names of pieces of clothing and accessories.
\end{abstract}

KEYWORDS: Language. Linguistics. Culture. Communication. Phraseological unit.

RESUMO: $O$ artigo trata da análise comparativa das unidades fraseológicas em inglês, alemão e russo com o componente "roupas", ou seja, nomes de acessórios, vestuários, peças de vestuário e calçados. A relevância da pesquisa é definida pelo interesse na interação entre diferentes linguagens e o processo de comunicação intercultural no mundo moderno. Um estudo profundo de expressões definidas ajuda a aprender o sistema único de linguagem que é característico de seus falantes nativos. O estudo das unidades fraseológicas com os nomes das roupas abre oportunidades para a compreensão da cultura tradicional, material e espiritual de uma nação. $O$ objetivo do estudo foi comparar unidades fraseológicas com o componente

\footnotetext{
${ }^{1}$ Kazan Federal University (KPFU), Kazan - Russia. Senior Lecturer of the Department of Theory and Practice of Translation. ORCID: https://orcid.org/0000-0001-5842-4453. E-mail: liya.1979@mail.ru

${ }^{2}$ Kazan Federal University (KPFU), Kazan - Russia. Senior Lecturer of the Department of Theory and Practice of Translation. ORCID: https://orcid.org/0000-0002-6701-6483. E-mail: olga.tari@mail.ru

${ }^{3}$ Kazan Federal University (KPFU), Kazan - Russia. Senior Lecturer of the Department of Theory and Practice of Translation. ORCID: https://orcid.org/0000-0003-0502-0126. E-mail: margarita7338@gmail.com
} 
"roupas" de três línguas: inglês, alemão e russo e realizar a análise quantitativa dessas unidades. Os autores usaram métodos como descritivo, comparativo, interpretativo, método de amostragem contínua e método estatístico. O objeto de estudo são diferentes tipos de unidades fraseológicas, incluindo provérbios e ditados, com os nomes de roupas pertencentes a cinco grupos temáticos: "vestimentas", "peças de vestuário", "materiais de vestuário", "acessórios" e "calçados". O estudo revelou que os maiores grupos temáticos de unidades fraseológicas são aqueles com nomes de peças de roupas e acessórios.

PALAVRAS-CHAVE: Língua. Linguística. Cultura. Comunicação. Unidade fraseológica.

RESUMEN: El artículo trata del análisis comparativo de las unidades fraseológicas inglesas, alemanas y rusas con el componente "ropa", es decir, los nombres de accesorios, prendas, prendas de vestir y zapatos. La relevancia de la investigación se define por el interés por la interacción entre diferentes lenguajes y el proceso de comunicación transcultural en el mundo moderno. Un estudio profundo de las expresiones establecidas ayuda a aprender el sistema de lenguaje único que es característico de sus hablantes nativos. El estudio de unidades fraseológicas con los nombres de las prendas abre oportunidades para comprender la cultura tradicional, material y espiritual de una nación. El objetivo del estudio fue comparar unidades fraseológicas con el componente "ropa" de tres idiomas: inglés, alemán y ruso y realizar el análisis cuantitativo de estas unidades. Los autores utilizaron métodos como descriptivo, comparativo, interpretativo, método de muestreo continuo y método estadístico. El objeto del estudio son diferentes tipos de unidades fraseológicas, incluyendo refranes y refranes, con los nombres de las prendas pertenecientes a cinco grupos temáticos: "prendas", "prendas de vestir", "materiales de vestir", "accesorios" y "zapatos". El estudio reveló que los mayores grupos temáticos de unidades fraseológicas son aquellos con nombres de prendas de vestir y accesorios.

PALABRAS CLAVE: Idioma. Lingüística. Cultura. Comunicación. Unidad fraseológica.

\section{Introduction}

Study of the phraseological units in various languages has a long tradition. For almost a century, phraseology has been the subject of research for linguists, which is proved by an extensive list of literature devoted to this issue. Phraseological units are characteristic of any language. They refer to phraseology which is a combination of set expressions inherent in any language and makes up the most vivid, colorful and peculiar part of the vocabulary (ARSENTEVA, 2010). The phraseology in a broad sense includes idioms, word collocations, phrasal verbs, proverbs, sayings and familiar quotations (COWIE, 1998). Linguists note that the vast majority of the phraseological units of the English, German and Russian languages belong to different functional styles, and the phraseological units themselves are expressive means (NACISCIONE, 2010). Even stylistically neutral phraseologisms can have national features and acquire expressiveness in certain contexts. 
Phraseological units with the component "clothes" occupy a special place in the phraseological fund. At the very early stages of the development of human society, clothing was not only a "protection" for people, but also symbolized important life processes and served as a ritual object. In this regard, clothes can be considered both as items and as signs characterizing their owners. Systematic study of the phenomenon of "clothing" allows creation of a model that integrates the universals of the traditional picture of the world (BABIYAN, 2017).

Clothes are an object of study of various scientific disciplines, such as archeology, ethnography, history and art history. A special place among these sciences is given to linguistics, as along with the fact that the vocabulary associated with clothes is an important historical and ethnographic source, it is undoubtedly of great interest from the linguistic point of view (ANDREYEVA; KORNEV; SAKHIBULLINA, 2019; AYUPOVA et al., 2020).

\section{Methods}

The article presents the results of analysis of 254 English, German and Russian phraseological units with the names of clothes selected by the continuous sampling method from the phraseological dictionaries: Phraseological dictionary of the Russian literary language by Fedorov (2008), Phraseological English-Russian dictionary by Litvinov (2008), EnglishRussian phraseological dictionary by Kunin (1998), English phraseological dictionary Oxford dictionary of English idioms (2009), The Farlex Idioms and Slang Dictionary (2017), GermanRussian phraseological dictionary by Binovich (1995).

Statistical, interpretative and descriptive methods were used for the analysis of the selected material. English, German and Russian phraseological units with the names of clothes were divided into five thematic groups: "garments", "clothing items", "clothing materials", "accessories" and "shoes". The statistical method was used to determine the frequency of various components of clothing in each thematic group in English, German and Russian. The descriptive and interpretative methods were applied to describe the phraseological units. The comparative method allowed revealing the general and specific trends of use of clothes names in set phrases in three languages. 


\section{Results and discussion}

The quantitative analysis of phraseological units with the component "clothes" showed that in the thematic group "garments" there are 47\% of the Russian, 28\% of English, and 25\% of German units under study. Phraseologisms having in their structure names of clothes which refer to the thematic group "clothing items" is presented by $55 \%$ of Russian, $22 \%$ of English and $23 \%$ of German units. The thematic group "clothing materials" includes $28.5 \%$ of Russian, $21.5 \%$ of English and $50 \%$ of German units. As for the group "accessories", the number of Russian, English and German phraseological units in this group is $41 \%, 38.5 \%$ and $20.5 \%$ correspondingly. In the thematic group "shoes" $27 \%$ of units are Russian, 50\% - English and $23 \%$ - German. The results of the analysis are presented in table 1.

Table 1 - Quantitative analysis of English, German and Russian phraseological units with names of clothes

\begin{tabular}{|l|c|c|c|}
\hline \multicolumn{1}{|c|}{ Thematic group } & $\begin{array}{c}\text { Russian } \\
\%\end{array}$ & $\begin{array}{c}\text { English } \\
\%\end{array}$ & $\begin{array}{c}\text { German } \\
\%\end{array}$ \\
\hline Garments & 47 & 28 & 25 \\
\hline Clothing items & 55 & 22 & 23 \\
\hline Clothing materials & 28,5 & 21,5 & 50 \\
\hline Accessories & 41 & 38,5 & 20,5 \\
\hline Shoes & 27 & 50 & 23 \\
\hline
\end{tabular}

Source: Prepared by the authors

Thus, phraseological units which can be referred to the thematic groups "garments", "clothing items" and "accessories" are mostly Russian, the units having names of clothing materials are predominantly German, and the names of shoes are the most recurrent in the English set expressions. The number of phraseological units with the names of garments and clothing items is almost the same in German and English.

The group "garments" includes phraseological units having the words clothes/clothing, odezhda and Kleidung in their structure as well. This group consists of 68 English, German and Russian phraseologisms in which 18 names of garments are used. The statistical analysis showed that among the total number of English, German and Russian phraseological units almost a third (29\%) contain a word shirt (рубашка, Hemd). The word pants (штаны, Hose) is used in $12 \%$ of set phrases belonging to the group "garments". In the third place are components "dress" and "clothes" (10\% each). The remaining 39\% of the analyzed phraseological units are set expressions with the names of different articles of clothing: "trousers", "uniform", 
“sarafan”, “cloak”, “jacket”, “caftan”, “coat”, “swimming trunks”, “vest”, “suit”, “fur coat”, "skirt", "stocking", "apron".

The word shirt (рубашка, Hemd) is the most recurrent in the thematic group "garments": lose one's shirt, a single thread from everyone - and there is a shirt for a naked one; das Hemd ist mir näher als der Rock, bis aufs Hemd ausziehen; родиться в рубашке, своя рубашка ближе к телу.

There are several hypotheses why this word is so frequently used in phraseological units of the languages under study. The first one is connected with the traditions of the Russian, English and German people. The shirt must be worn next to the skin by both men and women at any time of the year. It performed important functions. Its length, as a rule, almost to the knees, was a means of covering the reproductive organs. The shirt was considered as a means of protection from the evil eye in many cultures. It can be presumed, that such significance of the shirt in the culture of different nations explains the frequency of use of this word in set expressions, for example, in phraseological units with the meaning "to lose something important": to lose one's shirt, sein letztes Hemd verlieren.

Pants (штаны, Hose) is another popular component of phraseologisms: to wear the pants in one's family, to wear out the seat of one's pants; es ist Jacke wie Hose; выпрыгивать из штанов, просиживать штаны. The phraseological units to wear the pants in one's family, die Hose anhaben appeared at the time when only men wore pants and women were inferior in the family and society. These set phrases were used in relation to the dominating women. Units with this meaning are not observed in Russian.

The word clothes/clothing (одежда, одежка; Kleidung, Kleider) is used in the following phraseologisms: the emperor has/wears no clothes, a wolf in sheep's clothing; Kleider machen Leute; по одежке протягивать ножки; по одежке встречают, по уму провожают.

The idiom "the emperor has/wears no clothes" is attributed to the Hans Christian Andersen's fable "The Emperor's New Clothes" and is used to describe a situation in which everybody suddenly realizes that they were mistaken in believing that somebody/something was very good, important, etc. (THE FARLEX IDIOMS AND SLANG DICTIONARY, 2017).

Phraseological units with the components шуба (fur coat) and сарафан (sarafan) are found only in the Russian language: шубы не сошьешь, не от шубы рукав; сарафанное радио. Russia has always been the main supplier of natural fur to various countries and a fur coat has been the main attribute of the Slavic winter clothes since ancient times. As for sarafan, it is a unique element of the traditional Russian costume not observed in other cultures. 
The thematic group "clothing items" includes 64 phraseologisms with the words “pocket" (69\%), "sleeve" (17\%), "collar" (9\%), and "hem" (5\%).

The word pocket (карман, Tasche) is the most recurrent in this thematic group: to put a hole in one's pocket, to line one's own pockets; in der eigenen Tasche wirtschaften; бить по карману, набивать карманы.

In the 18th century a pocket was an essential element of a woman's costume and demonstrated the status of a person. Nobility wore pockets made of expensive fabrics, while others most often used linen. It is worth noting that at that time the pocket was not an item of clothing. It was not sewn on clothes and was used as an independent article of clothing. Today pockets are elements of different types of clothing: trousers, dresses, skirts, and so on, that is why they are often observed in the structure of phraseological units in three languages under study.

The word collar is observed in a set expression white-collar worker used in sociology and meaning "a person who performs professional, managerial, or administrative work". This unit was borrowed by the Russian language as a translation loan: белый воротничок. It is also used in the phrase white-collar crime.

Less frequent are components sleeve/hole (рукав, Ärmel): to roll up one's sleeves, to have an ace in the hole; die Ärmel hochkrempeln; закатать рукава, (работать) спустя рукава. The idiom to roll up one's sleeves which is found in all three languages has its origins in Kievan Rus' where both men and women used to wear long-sleeved clothes. It was uncomfortable to work in such clothes, so peasants rolled up their sleeves.

The thematic group "clothing materials" includes such components of phraseological units as feather (перо, Feder), thread (нить, Faden) and skin (шкура, Pelz): a feather in one's cap; sich mit fremden Federn schmücken; рядиться в чужие перья; ein Wolf im Schafspelz, волк в овечьей шкуре; Ariadne's thread; der Ariadnefaden; нить Ариадны. Most of the set expressions of this group are associated with different scriptures - Holy Sripture, ancient Greek scriptures, as well as fables.

The most recurrent component in the thematic group "accessories" is the word hat (шляпа, Hut): to take off one's hat, to eat one's hat; den Hut abnehmen, den Hut in den Ring werfen; дело в шляпе, съесть свою шляпу, кинуть шляпу на воздух. The words cap (шапка, Mütze) and glove (перчатка, Handschuh) are also frequently used in the analyzed phraseologisms: if the cap fits, wear it, cap of invisibility; eins auf die Mütze geben; шапканевидимка, на воре шапка горит, закидать шапками; the velvet glove; den Handschuh 
aufnehmen; бросить кому-л. перчатку. Other names of accessories observed in the structure of set expressions are bag, belt, belt, visor, cap, mittens, wallet, tie, glasses.

Components of phraseological units from the thematic group "shoes" are shoe, slippers, boot and galoshes: the shoe is on the other foot; das ist ein anderes paar Schuhe; сесть в калошу. Idioms with the word heel (каблук, Absatz) also belong to this group: to be down at (the) heels; an den Absätzen abgelaufen sein; быть под каблуком.

\section{Summary}

Clothes are studied both within the framework of individual disciplines, including linguistics, and in on the interdisciplinary level. This paper shows the significance of such studies. The phenomenon "clothes" is very unstable: due to the changes in economic, social and cultural life the clothes themselves, their functions and the processes of their manufacturing are changing.

Clothing not only protects the body, it is a certain artistic system that characterizes an individual (KOZLOVA, 1980). The concept of "costume" includes clothing, shoes, hairstyle, headwear, gloves, jewelry, makeup, etc. The costume contains figurative and psychological characteristics of a person, highlights their social and cultural identity.

The study of phraseological units associated with clothing should be closely related to the development of the material culture of the nation, with its historical, cultural, economic relationships with other peoples at different stages of its formation (ABROSIMOVA et al., 2018). When analyzing phraseological units, the systemic nature of a particular group should be taken into account. In modern linguistics such analysis is based on the traditional method of describing vocabulary in thematic groups, which allows establishing a connection between words and designated phenomena, reveals the word meaning, the peculiarities of its use and its role in the language.

\section{Conclusions}

The paper presents the results of the analysis of the Russian, English and German phraseological units with the names of clothes which were divided into five thematic groups: "garments", "clothing items", "clothing materials", "accessories" and "shoes".

The phraseological units with the names of garments are rather numerous. The word shirt (рубашка, Hemd) is the most frequently used name of articles of clothes in all three 
languages. However, some names of garments are structural components of phraseologisms only in one language; for example, the word шуба (fur coat) is used only in the Russian language.

The words pocket, sleeve, collar and hem comprise the thematic group "clothing items". The component pocket is the most recurrent in English, German and Russian idioms in comparison with other names of clothing items.

The most frequently used names of accessories are hat, cap and glove. Components of phraseological units from the smallest thematic group "clothing materials" are feather, thread and skin. The words shoe, slippers, boot, galoshes and heel are also found among the names of clothes used in set phrases.

The number of phraseological units with the components "clothes" is associated with the history and origin of a certain article of the clothing. Some units stem from the works of famous writers like Charles Dickens and Hans Christian Andersen, as well as from ancient Greek myths (the thread of Ariadne), fables and scriptures, the Bible in particular (a wolf in sheep's clothing).

ACKNOWLEDGEMENTS: The work is performed according to the Russian Government Program of Competitive Growth of Kazan Federal University

\section{REFERENCES}

ABROSIMOVA, G. et al. Incentive modality in tatar and english languages. Information an International Interdisciplinary Journal, v. 21, n. 5, p. 1563-1572, 2018.

ANDREYEVA, Y. A. KORNEV, I. G. A.; SAKHIBULLINA, K. A. Values and anti-values in figurative phraseological units in the Russian and German languages. Humanities and Social Sciences Reviews, v. 7, n. 4, p. 427-432, 2019.

ARSENTEVA, E. F. New trends in lexicography: ways of registering and describing lexis. In: The main problems of multilingual phraseological dictionary compilation. Cambridge Scholars Publishing, 2010.

AYUPOVA, R. et al. Identifying the key components of phraseological units. Humanities and Social Sciences Reviews, v. 8, n. 1, p. 233-239, 2020.

BABIYAN, T. V. Proverbs and sayings as means of linguiocultural realia representation. Filologicheskie nauki. Voprosy teorii i praktiki, v. 10, n. 76, p. 48-50, 2017.

BINOVICH, L. E. Nemecko-russkij frazeologicheskij slovar'. Akvarium, 1995. 
COWIE, A. P. Phraseology: theory, analysis and applications. Oxford University Press, 1998.

FEDOROV, A. I. Frazeologicheskij slovar'russkogo literaturnogo yazyka: ok. 13000 frazeologicheskih edinic. Astrel: AST, 2008.

KOZLOVA, T.V. Kostyum kak znakovaya sistema (Suit as a sign system). MTI, 1980.

KUNIN, A. V. English-russian phraseological dictionary. Zhivoy yazyk, 1998.

LITVINOV, P. P. 3500 anglijskih frazeologizmov i ustojchivyh slovosochetanij. Astrel: AST, 2007.

NACISCIONE, A. Stylistic use of phraseological units in discourse. John Benjamins Publishing, 2010.

OXFORD DICTIONARY OF ENGLISH IDIOMS. Oxford University Press, 2009.

THE FARLEX IDIOMS AND SLANG DICTIONARY. CreateSpace Independent Publishing Platform, 2017.

\section{How to reference this article}

YUSUPOVA, L. G.; KUZMINA, O. D.; GUSEVA, M. I. Phraseological units with names of clothes in english, german and russian. Rev. EntreLínguas, Araraquara, v. 7, n. esp. 3, e021054, Sep. 2021. e-ISSN: 2447-3529. DOI: https://doi.org/10.29051/el.v7iesp.3.15715

Submitted: $10 / 01 / 2021$

Required revisions: 20/03/2021

Approved: $23 / 06 / 2021$

Published: 01/08/2021 